\title{
Mystical Experience
}

\subsection{Introduction}

This chapter focuses on mystical experiences among our sample of college and university students in Tamil Nadu. With due regard to Stace's view (1961:21) that "nearly all men are in some sense or other rudimentary or unevolved mystics", we analyse mysticism as "a normal phenomenon reported by healthy and functioning persons struggling to find a meaningful framework in which to live out their experience as foundational - as at least what is real for them, if not in some sense as the ultimate 'Real'" (Hood et al. 1996:267).

First we outline the theoretical framework of mystical experience propounded by Stace (1961), which forms the basis of Hood's Mysticism Scale (4.2). Then we list the research questions and describe the construction of our measuring instrument based on Hood's Mysticism Scale (Hood 1975; Hood, Morris \& Watson 1993; Hill \& Hood 1999; Hood \& Williamson 2000), followed by the results of our analyses. Insofar as mystical experience can be linked to personal characteristics we consider its social location, as well as socio-cultural and socio-economic attributes as socio-religious predictors of mysticism (4.3). Finally we discuss the significance of the comparative model of mystical experience (4.4).

Although the Reinert and Stifler (1993) replication of Hood's scale included some Hindu and Buddhist monks and nuns, no comparison based on religious affiliation was reported. Hood et al. (2001) did compare Christians and Muslims using the same mysticism scale. Our comparative research goes beyond these attempts by comparing Hindus with Christians and Muslims, testing for one-dimensionality and scalar invariance. Our comparative study attempts to meet a long felt need underscored by Hood et al. (2001:704). In their view, if comparison of Christianity and Islam is pertinent because both are monotheistic religions with shared historical roots, it is even more challenging to compare them with Hindus because it might yield very different findings.

\subsection{Theoretical Framework}

Hood's Mysticism Scale is based in part on Stace's conceptual framework of mysticism. In his seminal work Stace (1961) outlines a conceptualization of

(C) ANTHONY, HERMANS \& STERKENS, 2015 | DOI 10.1163/9789004270862_006

This is an open access chapter distributed under the terms of the Creative Commons Attribution-

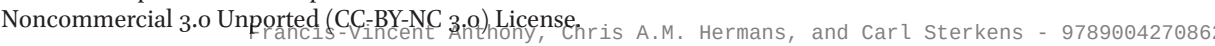


mysticism that is cross-cultural, a-historical and unbiased by religious ideology. His conceptual framework is based on three constructs: (a) a distinction between mystical consciousness and its interpretation; (b) a distinction between extrovertive and introvertive mysticism and their core characteristics; and (c) identification of universal common characteristics (see Table 4.1).

(a) Stace $(1961,31)$ distinguishes between mystical consciousness and its interpretation on the basis of his inquiry into Christian, Islamic, Judaic, Hindu, Buddhist and Taoist mystical experience. He considers it analogous with the distinction between sensory experience and its interpretation, and concedes that we may never come across altogether uninterpreted experience. Nevertheless he $(1961,66)$ recognizes the directness and seemingly un-interpreted state of unity in mysticism: "The unity is perceived, or directly apprehended. That is to say, it belongs to experience and not to the interpretation, insofar as it is possible to make this distinction." Stace uses the term "mystical consciousness' in this context, but not always consistently; sometimes he equates it with 'mystical experience', which also includes interpretation of the state of union.

In our view this state of union belongs to the realm of mystical consciousness rather than that of interpretation. Empirical research supports the claim that mystical consciousness and its interpretation can be relatively independent (cf. Hood \& Williamson 200o). Mystical experience as a concept entails distinct but not separable aspects of consciousness of union and its interpretation. While mystical consciousness - in Stace's perspective - is basically similar all over the world in different periods and religious contexts, mystical experiences can vary insofar as the interpretations of this state of union may differ from one religious tradition to another.

(b) Stace's second distinction is between extrovertive and introvertive mystical experience, based on the source of the stimuli that lead to the experience of union. "The essential difference between them is that extrovertive experience looks outward through the senses, while introvertive experience looks inward into the mind. Both culminate in perception of an ultimate unity - what Plotinus called the One - with which the perceiver experiences union or even identity. But extrovertive mystics using their physical senses perceive a multiplicity of external material objects - sea, sky, houses, trees - mystically transfigured so that the One or Unity shines through them. Introvertive mystics, on the other hand, by deliberately shutting off the senses and obliterating from consciousness the entire multiplicity of sensations, images, and thoughts, seek to plunge into the depths of their own egos. There, in that darkness and silence, they claim to perceive the One and be united with it - not as a Unity seen through multiplicity (as in extrovertive experience), but as the wholly naked One devoid of any pluralism whatever" (Stace 1961, 61f). 
Stace identifies two core characteristics of extrovertive and introvertive mysticism. Extrovertive mysticism is characterized by awareness of unity with the universe or the perception of all things as one (unifying quality), and by apprehension of the One as inner subjectivity or life in all things (inner subjective quality). In introvertive mysticism the experience of union refers to a 'pure' state, in the sense that the mystical consciousness has no substantive content and is even characterized by a loss of self (ego quality). Such consciousness of nothingness is accompanied by distortion of time and space (spatio-temporal quality). Stace $(1961,86-87)$ describes it as follows: "When the self is not engaged in apprehending objects it becomes aware of itself. [...] One may also say that the mystic gets rid of the empirical ego whereupon the pure ego, normally hidden, emerges into the light. The empirical ego is the stream of consciousness. The pure ego is the unity which holds the manifold of the stream together. This undifferentiated unity is the essence of the introvertive mystical experience."

These descriptions of the very essence of mystical experience suggest that the extrovertive type "is an incomplete kind of experience which finds its completion and fulfillment in the introvertive kind of experience. The extrovertive kind shows a partly realized tendency to unity which the introvertive kind completely realizes" (Stace 1961, 132). By pointing out the interconnection between extrovertive and introvertive consciousness Stace underscores that mystics themselves generally do not distinguish between the two types, indicating that there is also a wider set of characteristics common to both extrovertive and introvertive mystical consciousness.

(c) These common characteristics of mystical experience, Stace claims, are universal in all cultures, religions and ages. He identifies five psychological and phenomenological common characteristics that can be seen as universal factors directing the interpretation of mystical consciousness: noetic quality (perception of special knowledge or insight), ineffability (difficult to articulate), positive affect (experience of peace or bliss), religious quality (perception of sacredness or wonder), and paradoxicality (Stace 1961, 31-37, 131-132; cf. Hill \& Hood 1999, 364).

Following Hood et al. (1996, 257-258), we may sum up the three fundamental assumptions in Stace's proposal as follows: first, despite variations in interpretation, mystical consciousness is universal and essentially identical among people; second, conceptually there is a clear distinction between introvertive and extrovertive forms of mysticism; third, although there is a set of common core characteristics, mystical experience need not always possess all of them, since there can be borderline cases. 
TABLE 4.1 Common core theory of mystical experience (Stace 1961).

\begin{tabular}{cc}
\hline \multicolumn{2}{c}{ Core Characteristics } \\
Extrovertive consciousness & Ego quality \\
\hline $\begin{array}{c}\text { Unifying quality } \\
\text { Inner subjective quality }\end{array}$ & Temporal-spatial quality \\
\hline Common characteristics \\
\hline \\
Noetic quality \\
Ineffability \\
Positive affect \\
Religious quality \\
Paradoxicality \\
\hline
\end{tabular}

Stace's common core theory has been challenged by Katz (1978) and others, who favour diversity theory and "argue that no unmediated experience is possible, and that in the extreme, language is not simply used to interpret experience but in fact constitutes experience" (Katz 1978, 256). Here the category 'consciousness' may help to clarify that, whereas we can speak of 'pure consciousness' without interpretation or qualification, experience is always interpreted. The opposition between common core theory and diversity theory is compounded by Stace's identification - at times - of consciousness with experience. As explained above, mystical experience can be seen as comprising both mystical consciousness (consciousness of union with reality/Reality) and its interpretation. While in some cases we may speak of un-interpreted pure consciousness, mystical experience always entails a greater or lesser degree of interpretation of the consciousness of union.

\subsection{Empirical Research}

\subsubsection{Research Questions}

Against the background of the conceptual framework of mystical experience, our research questions are the following: 
(1) What comparative model of mystical experience emerges among Christian, Muslim and Hindu students once group-specific differences have been ascertained?

(2) Are there significant differences in the levels of mystical experience between Christian, Muslim and Hindu students?

(3) Which personal (socio-cultural, socio-economic and socio-religious) characteristics relate to the level of mystical experiences among Christian, Muslim and Hindu college students?

(4) To what extent can agreement with mystical experience among Christian, Muslim and Hindu college students be ascribed to personal (socio-cultural, socio-economic and socio-religious) characteristics?

\subsubsection{Measuring Instrument}

The measuring instrument is based on Hood's Mysticism Scale. Empirically this scale has proved apposite in diverse cultural contexts and religious traditions (Hood 1975; Holm 1982; Hill \& Hood 1999; Hood et al. 2001). Hood's Mysticism Scale comprises 32 items, half of which are formulated negatively to prevent response set. Originally eight common core characteristics of Stace's concept of mystical experience were operationalized in four items each, but empirical testing led to reporting on mysticism at a more general level. Hood (1975) famously reported a two-component structure, the first corresponding to experience of union, the second being religious interpretation. Caird (1988) and Reinert and Stifler (1993) proposed a three-factor mysticism scale, compatible with Stace's conceptualization: extrovertive mysticism (experience of union with the external world) with twelve items; introvertive mysticism (experience of nothingness) with eight items; and religious interpretation with twelve items (Hood, Morris \& Watson 1993; Hood \& Williamson 2000).

Since mystical experience is only one of many themes in our overall crossreligious study, we abridged the measuring instrument to twelve items. This was possible because Hood's scale of 32 items consists partly (16 items) of negative formulations, which to a great extent simply reverse the positive formulations. We opted for positive formulations in accordance with our answer format. Each dimension (extrovertive mysticism, introvertive mysticism and religious interpretation) is covered by four items. Our choice of items is based on the inter-item correlations in Hood's initial study (1975) and the results of our own pilot study. Since English is the educational medium (at colleges) of all respondents, it was unnecessary to translate the items. However, it should be noted that linguistic considerations can play a role in evaluating the appropriateness of an instrument in a multilingual context (Van de Vijver \& Leung 1997, 38-40). 
Note that in Hood's original scale (1975) - which he later abandoned in favour of the three-factor model - the items selected by us represented the eight common core characteristics of mystical experience as follows: ego quality (items $5,6,11$ ), spatio-temporal quality (item 2), unifying quality (items 9, 12), inner subjective quality (item 3), noetic quality (items 1, 7), ineffability (item 8), positive affect (item 10) and religious quality (item 4).

Hood used a four-point Likert-type response format ranging from +2 ('this description is definitely true of my own experience/s') to -2 ('this description is definitely not true of my own experience/s'), with no midpoint but with the additional option, 'I cannot decide'. The original format of the item (e.g. "I have had an experience in which a new view of reality was revealed to me") seemed weighted in favour of a positive response and was rather indirect in its approach to respondents' mystical experience. In Hood's formulation the respondents had to choose between 'This description is probably (or definitely) true/ not true of my own experience/s'. We opted for a more direct formulation of items and responses. For example, our item 7 reads "Did you ever have an experience in which a new view of reality was revealed to you?" The respondents could answer on a four-point Likert scale: 'Certainly no', 'Probably no', 'Probably yes', 'Certainly yes'. The complete list of twelve items appears in appendix D.

\subsubsection{Results of Empirical Analysis}

Research question 1: What comparative model of mystical experience emerges among Christian, Muslim and Hindu students once group-specific differences have been ascertained?

In constructing a comparative model of mystical experience we followed the analysis procedure described in chapter $1(1.7)$. When free factor analysis (step one) was run on items manifesting strong correlations $(6,7,8,11,12)$, they yielded a single factor. In the second factor analysis of the five items for the three religious groups separately, item 12 had to be removed because of low commonality in the case of Christians and Muslims. We found that item 12 ("Did you ever have an experience in which you realized your oneness with all things?") yields low commonality in the case of Christians and Muslims. In the case of Hindus, by contrast, it has quite a high factor loading (.51). In Stace's conceptual framework, item 12 represents 'unifying quality', one of the core characteristics of extrovertive consciousness. It means that the comparative model underrepresents the experience of mystical union with all reality (perception of oneness) in the case of Hindus. We shall discuss this difference in more detail in the final section. 
TABLE 4.2 Factor analysis (PAF, Oblimin rotation), commonalities $\left(h^{2}\right)$, percentage of explained variance, and reliability (Cronbach's alpha) of comparative mystical experiences among Christian, Muslim and Hindu students.

F1 $\quad h^{2}$

7. Did you ever have an experience in which a new view of reality was revealed to $\quad .56 \quad .32$ you?

11. Did you ever have an experience in which something greater than yourself $\quad .49 \quad \begin{array}{ll}.24\end{array}$ seemed to absorb you?

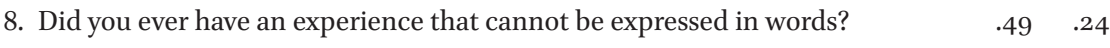

6. Did you ever have an experience in which your own self seemed to merge into $\quad .48 \quad .23$ something else?

Cronbach's alpha $\quad .58$

Number of valid cases $\quad 1869$

Scale: $1=$ =Certainly no; $2=$ Probably no; $3=$ Probably yes; $4=$ =Certainly yes Explained variance $=25.8 \% ; \mathrm{F} 1=$ Vertical mysticism; $\mathrm{N}=1920$.

Table 4.2 presents results from the third step, namely Principal Axis Factoring (Oblimin rotation method) of the four remaining items for the entire group of students. The third factor analysis results in a moderately reliable measuring instrument that can be used to compare mystical experience in the three religious traditions. Note that the four items of the comparative model of mystical experience concern the core characteristic of ego quality, namely loss of self (items 6,11 ), and the common characteristics of noetic quality (item 7) and ineffability (item 8 ). These common core characteristics can be considered central in comparative measurement of mystical experiences.

Items 6 and 11 represent the (complementary) active and passive aspects of mystical union implying loss of self: on the one hand it is an experience in which one's self seems to merge into something else (item 6), on the other it is an experience in which something greater than oneself seems to absorb the self (item 11). Although in Hood, Morris and Watson's (1993, 1177) three-factor analysis item 6 emerged as part of extrovertive mysticism, we have seen that in Hood's original scale ("form D") items 6 and 11 represented ego quality (loss of self) that is central in introvertive mysticism (Hood 1975, 31). Hence these two items in our comparative factor point to one of the core characteristics of introvertive mysticism, namely, loss of self in the experience of union with a higher reality.

The other two items (7 and 8) of our comparative model concern the common characteristics of noetic aspect and ineffability. In Stace's theoretical 
framework ineffability ("an experience that cannot be expressed in words", item 8) is one of the common characteristics, but in Hood's empirical study it turns out to be a characteristic of introvertive mysticism. In the three-factor solution (Hood et al. 2001, 694, 702) among Iranian Muslims the characteristic of ineffability fits the interpretation and introvertive factors equally well. In the case of us Americans, however, ineffability is indicative of introvertive mysticism. The significance of ineffability seems to vary according to religiocultural setting. Caird's study $(1988,125)$ of a small sample of 115 respondents tends to confirm Stace's view of ineffability rather than Hood's. The study by Reinert and Stifler $(1993,387)$ also confirms ineffability as part of the common interpretive categories. We conclude, therefore, that the interpretive category of ineffability has a particular affinity with introvertive mysticism.

Item 7 ("an experience in which a new view of reality was revealed") has the highest factor loading (.56). In Hood's three-factor solution items on the noetic aspect form part of the interpretive category. This accords with Stace's definition of the noetic aspect as a common characteristic that can qualify both introvertive and extrovertive mysticism. Two items in our comparative model (items 6 and 11) deal with the active and passive aspects of loss of self in the union with a greater reality, which is the core of introvertive mystical consciousness. The other two interpretive items (items 7 and 8) concern the noetic quality of this union (leading to perception of new insight) and its ineffable nature (experience of union being difficult to articulate). In its composition the comparative model of mystical experience thus represents a revelatory and an ineffable experience of union with a greater or higher reality. Hence we label it 'experience of mystical union with a higher reality' or 'vertical mysticism'.

The reliability $(\alpha .58)$ and percentage of explained variance $(25,8 \%)$ of the comparative model of mystical experience are moderate for the whole group (Table 4.2.), and remain almost unaltered when each of the three religious groups is examined separately. We further tested, via confirmatory factor analysis, whether the measurement model is the same for all groups, and whether the factor loadings are the same across groups. Analysis of the data with Lisrel 8.8 (Jöreskog \& Sörbom 2012) resulted in an acceptable model fit for the test of scalar invariance $\left(\mathrm{X}^{2}[\mathrm{df}=18]=38.75 ; \mathrm{RMSEA}=0.043 ; \mathrm{GFI}=0.99\right)$. This means that we can assume that the measurement model is equivalent for the three different religious groups (Christian, Muslims and Hindus) and allows meaningful comparison between these groups.

Research question 2: Are there significant differences in the levels of mystical experiences between Christian, Muslim and Hindu students? 
TABLE 4.3 Levels of agreement (mean and standard deviation) with regard to vertical mysticism for Christian, Muslim and Hindu students; and comparison of means between religious groups of respondents (Scheffe's test: F-value: 27.81 ; sign. <.0oo).

\begin{tabular}{llllll}
\hline & N & Mean & S.d. & Muslims & Hindus \\
\hline Christians & 852 & 3.13 & .61 & & $* *$ \\
Muslims & 237 & 3.05 & .63 & & $*$ \\
Hindus & 773 & 2.89 & .67 & $*$ & \\
\hline
\end{tabular}

Scale: $1=$ Certainly no; $2=$ Probably no; $3=$ Probably yes; $4=$ =Certainly yes. Intergroup differences are significant at $\mathrm{p}<.000\left({ }^{* *}\right)$ or $\mathrm{p}<.005$ level $\left({ }^{*}\right)$.

As shown in Table 4.3, the experience of vertical mysticism reported by Hindus tends slightly towards ambivalence (mean 2.89), whereas Christians and Muslims evaluate it as 'probably yes' (means 3.13 and 3.05 respectively).

Hindus are found to differ significantly from both Christians and Muslims (Scheffe's test: F-value: 27.81 ; sign. <.0oo). We would have expected them to manifest a higher level of involvement, for mysticism is a key component of Hinduism, being both its source and its centre. In Christianity and Islam it is only a minor strand (Stace 1961, 342-343). The lesser involvement indicated by the Hindus' tendency towards ambivalence suggests that vertical mysticism may not be as important for them as for Christians and Muslims. At the same time there is evidence that the comparative model underrepresents mystical union with all reality, thus inadequately reflecting Hindu experience.

Research question 3: Which personal (socio-cultural, socio-economic and socio-religious) characteristics relate to the level of mystical experience among Christian, Muslim and Hindu college students?

This question concerns the social location of vertical mysticism. What are the personal characteristics of people who experience mystical union with a higher reality? We describe the significant correlations for each group of students separately (Table 4.4).

Among Christian students females report a higher level of vertical mysticism (.12). In the case of Christians four socio-religious characteristics are connected with vertical mysticism: perceived positive influence of friends, the religious community, teachers/professors and the media. The strongest association is with the influence of teachers/professors on religiosity (.19).

In the case of Muslim students only socio-religious characteristics are connected with vertical mysticism: influence of relatives, the religious community, 
TABLE 4.4 Social location of vertical mysticism among Christian, Muslim and Hindu students. Correlations (eta for the nominal variables sex and language; Pearson's $r$ for the other, ordinal variables) between vertical mysticism and some personal characteristics. $^{1}$

\begin{tabular}{|c|c|c|c|}
\hline & Christians & Muslims & Hindus \\
\hline \multicolumn{4}{|c|}{ Socio-cultural characteristics } \\
\hline Gender & $.12^{* *}$ & & $.10^{* *}$ \\
\hline Language & & & $.09^{*}$ \\
\hline \multicolumn{4}{|c|}{ Socio-religious characteristics } \\
\hline Parents & & & $.08 *$ \\
\hline Relatives & & $.23^{* *}$ & $.10^{* *}$ \\
\hline Friends & $.12^{* *}$ & & $.08^{*}$ \\
\hline Religious community & $.12^{* *}$ & $.15^{*}$ & $.14^{* *}$ \\
\hline Teachers/professors & $.19^{* *}$ & $.16^{*}$ & $.18^{* *}$ \\
\hline Media & $.14^{* *}$ & $.20^{* *}$ & $.13^{* *}$ \\
\hline
\end{tabular}

All correlations are significant at $\mathrm{p}<.00$ level $(* *)$ or $\mathrm{p}<.05$ level $\left({ }^{*}\right)$.

teachers/professors and the media. The strongest associations are with the positive influence of relatives (.23) and the media (.20).

Among Hindu students females report a higher level of vertical mysticism than men (eta .10) and Tamil speakers (.og). For the rest all socio-religious characteristics correlate significantly with vertical mysticism. The strongest association is with the perceived positive influence of teachers/professors on religiosity (.18).

Research question 4: To what extent can agreement with mystical experience among Christian, Muslim and Hindu college students be ascribed to personal (socio-cultural, socio-economic and socio-religious) characteristics?

The results of the regression analysis are rather disappointing (Table 4.5). Among Christian and Hindu students only the influence of the media on their religiosity is a significant predictor. The level of explained variance (.02) in both groups is too low to be theoretically relevant. No other personal characteristic predicts the level of agreement with vertical mysticism.

1 The following characteristics did not show significant correlations for any of the groups of respondents: age, urbanization, field of specialization, caste, educational level of the father and educational level of the mother. These variables are not mentioned in the table. 
TABLE 4.5 Regression analyses for vertical mysticism with weights $(\beta)$ for each variable and total explained variance $\left(R^{2}\right.$ and adjusted $\left.R^{2}\right)$ for Christian, Muslim and Hindu students separately.

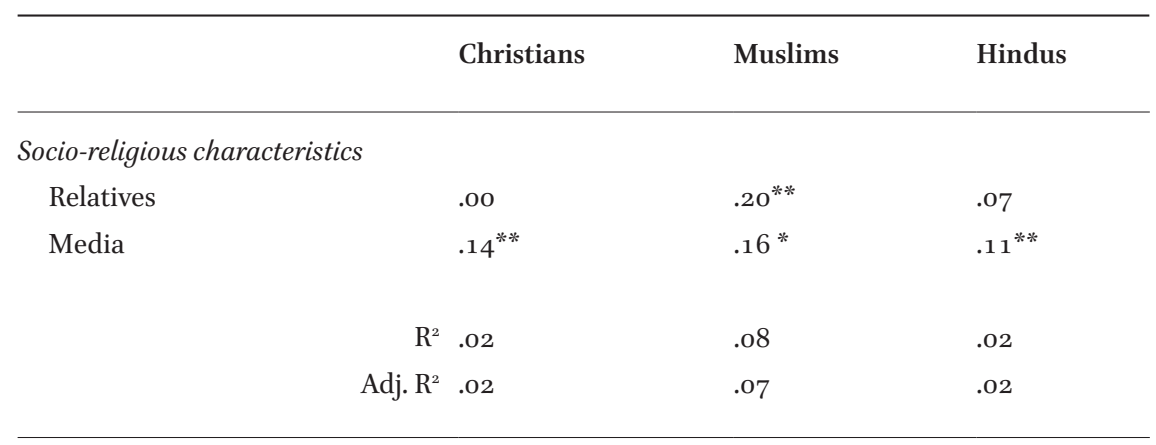

Standardised regression coefficients $(\beta)$ are significant at $\mathrm{p}<.00\left({ }^{* *}\right)$ or $\mathrm{p}<.05\left(^{*}\right)$ level.

In the case of Muslim students the analysis shows two predictors which explain $8 \%$ of the variance $\left(\mathrm{R}^{2} .08\right.$; Adj. $\left.\mathrm{R}^{2} .07\right)$. This level of explained variance is low, but it gives a theoretically relevant profile of Muslim students' level of agreement with vertical mysticism. Two socio-religious characteristics predict a higher level of agreement, namely influence of relatives $(\beta .20)$ and of persons in media linked to one's religion ( $\beta$.16). Positive influence of relatives is the strongest predictor and refers to the context of primary religious socialization (i.e. the extended family). But public figures linked to their own religion is a strong predictor of vertical mysticism among Muslim students. No other characteristic (socio-cultural or socio-economic) predicts a higher level of agreement with vertical mysticism. In the case of Muslim students vertical mysticism is influenced by religious models close to them (relatives) and in the media. The more strongly Muslim students are influenced by these religious models, the more they report experiences of vertical mysticism.

\subsection{Findings and Discussion}

Our points of discussion refer to the research questions: the comparative measurement of vertical mysticism (research questions 1 and 2); and the impact of personal characteristics on vertical mysticism (research questions 3 and 4 ).

\subsubsection{Significance of a Comparative Model of Vertical Mysticism}

The comparative model of vertical mysticism or mystical union with a higher reality emerging from our analysis is significant for three reasons. In the first 
place, it is the outcome of a procedure to establish measurement equivalence that has not been used before in conjunction with the Mysticism Scale. Secondly, as far as comparison between religious groups is concerned, the only study has been that of Hood et al. (2001), which included 188 us Americans (mostly Christians) and 185 Iranian Muslims, with separate factor analyses for each group. In our research 1.920 respondents belonging to the Christian, Islamic and Hindu traditions form a single sample and are compared substantially. Thirdly, from the perspective of Stace's common core theory, as will be seen below, the comparative model offers new insights and prospects.

In our comparative model of vertical mysticism one of the core characteristics of introvertive mysticism, namely a sense of loss of self, combines with the common characteristics of noetic quality and ineffability. It suggests that vertical mysticism has a revelatory, ineffable character. This set of common core characteristics is comparable in the experience of Christians, Muslims and Hindus. However, the model seems to represent only one type of mystical experience, namely mystical union with a higher reality or 'vertical mysticism'. In a way vertical movement in mysticism characterizes Semitic religions. It is alluded to, for example, in the classic of Christian mysticism, The ascent of Mount Carmel by St John of the Cross (1542-1591), and in more humanistic terms in The ascent of Mount Ventoux by Francesco Petrarca (1304-1374), the first modern scholar and man of letters (Robinson 2003). Our research shows that Christian and Muslim students report a significantly higher level of vertical mystical experience than Hindu students. In the case of Muslim students our findings reveal that some socializing agents (relatives and the media) influence the level of vertical mysticism.

While Christians and Muslims are positive about vertical mysticism, Hindus tend towards ambivalence. Moreover, in the case of Hindus the comparative model of mystical experience underrepresents mystical union with a wider reality, one of the core characteristics of extrovertive consciousness (perception of oneness). This is significant, as in the Hindu tradition introvertive search for the ultimate ground of one's being leads to discovery of Ätman and extrovertive search for the ground of all reality leads to discovery of Brahman. The search culminates in the realization that Atman is identical with Brahman (Ayam Ātma Brahma, as stated in Māṇ̂ūkya Upanișad, 2).

Recognizing that the ground of one's being is identical with the ground of all reality is characteristic of Hindu mystical tradition. Since this ultimate ground, Brahman, is consciousness (Prajñānam Brahma, as stated in Aitareya Upanișad III, v, 3), in Hindu tradition mystical experience is pure consciousness. In the Vedantic tradition Sankara (788-820) with his philosophy of advaita (non-dualism) and Ramanuja (1017-1118) with his Visisịțādvaita (qualified 
non-dualism) are leading exponents of the nature of consciousness. For Sankara and the advaita school consciousness is pure light shining by itself without any subject-object distinction, whereas for Ramanuja and the bhakti (devotional) tradition consciousness is a relationship of illumination. Notwithstanding the differences, Sankara and Ramanuja assume consciousness to be the essential nature of spirit, namely of Brahman and the individual soul, and on this basis they interpret the nature of the phenomenal world (Chethimattam 1996, 34 and 96; 1971, 54). In the experience of recent mystics like Ramana Maharishi (1879-1950) from Tamil Nadu and Sri Ramakrishna (1834-1886) from Bengal the difference between the two philosophical traditions is perceived as basically a matter of vantage points (Easwaran 1988, 30; Sharma 1993). In relation to the external phenomenal world advaitic and Visisistāadvaitic consciousness, by underscoring the radical interdependence of all reality, tends to evoke a monistic or pantheistic mystical experience. As mentioned already, our comparative model of mystical experience was found to underrepresent this mystical union with a wider reality in the case of Hindus. It suggests the possibility of horizontal mysticism (union of self with a wider reality) as distinct from vertical mysticism (mystical union with a higher reality), which is more compatible with the Christian and Islamic traditions.

Our model includes the comparable elements of vertical mysticism, which is particularly dominant in the Semitic religions (Judaism, Christianity and Islam). Such mysticism generally has a revelatory component and is not easy to articulate (ineffable). In the context of these religions mysticism entails union of the self with the higher reality of God, who sometimes reveals himself and his intentions in an ineffable manner. By contrast Oriental religions like Hinduism and Buddhism tend to emphasize horizontal mysticism in their introvertive and extrovertive search for the ultimate. It leads to union of self with a wider reality, an experience of the radical interdependence of all reality in a non-dualistic sense. The final phase of such mysticism is total loss of self or total realization of Self in pure consciousness.

In this conceptualization loss of self implies emergence of the ultimate reality as pure consciousness. In the Semitic religions there is a strong tendency to see this reality as beyond or above the world as we experience it. This reality is one, absolute and the ultimate ground of the self. The true self is embedded in this reality. By analogy with a distinction made in philosophy of mind (Searle 1985) we could speak of a self-to-God direction of fit. ${ }^{2}$ The truth of the self is

2 Searle (1985) distinguishes between a mind-to-world direction of fit and a world-to-mind direction of fit. An example of the former is beliefs. The truth of beliefs about the world is decided by their fit with the state of affairs of the world. A belief is satisfactory when it depicts 
decided by the fit of the self with the nature of the absolute reality. Loss of self implies a transformation of the self according to divine reality. The self should mirror this reality, which is beyond anything in the world (including the self). Vertical mysticism is characterized by a self-to-God direction of fit. Horizontal mysticism, on the other hand, can be seen as characterized by a God-to-self direction of fit. It is characterized by the perception of all things as one, that is by the idea that the divine reality is present in all things (including the self). This implies transformation of the divine reality in order to fit the reality of all things, hence not so much a loss of self as a self that becomes one with this reality. The perception of all things as one is the result of a process of transformation in which the divine reality is realized in all things (including the self). By using the concept of direction of fit we suggest that the movement in vertical mysticism differs from that in horizontal mysticism. In vertical mysticism the divine reality transcends or is beyond the world as we experience it. hence it implies a loss of self because the truth of the self is in God. In horizontal mysticism the divine reality is immanent, that is it is present in everything we experience. Therefore the self should be transformed in conformity with this all pervading divine reality, or brought to God-realization.

The foregoing discussion elucidates that the theoretical distinction between vertical and horizontal mysticism could be fruitful for further comparative research into religious mysticism. In our opinion it might be more fruitful than the introvertive and extrovertive distinction proposed by Stace. The qualifications 'introvert' and 'extrovert' refer more to the (perceived) origin of the mystical consciousness than to the experience of the reality/Reality as such. In other words, vertical and horizontal mysticism may be better categories for interpreting mystical experience.

In addition our research may shed some light on the unresolved debate between Stace's common core theory and Katz's diversity theory. Is there a common structure of mystical experience for all religions (cf. Stace's common core theory) or do religions differ in regard to the type of mystical experience (cf. Katz's diversity theory)? With reference to vertical and horizontal mystical experience the question could be viewed as follows: if Stace is correct, both types of mysticism are present in all religions, and if Katz is right, both types may not be present in all religions, that is religions will differ with regard to specific types of mystical experience. If we consider the results of our research, we find some ground for the Katz's diversity theory. In the process of establishing

the world adequately. A desire is an example of a world-to-mind direction of fit. The idea is that usually a desire is not yet realized in that it does not refer to a state of affairs in the world. Instead the world is transformed in such a way that is fits the desire. 
measurement invariance we had to remove items which can be regarded as belonging to a horizontal model of mystical experience (i.e. oneness with all reality). The items did not seem to fit the mind-set of our Christian and Muslim students.

In the case of Christians this may be due to fear of syncretistic fusion with monistic or pantheistic tendencies. For example, in its Letter to the bishops of the Catholic Church on some aspects of Christian meditation the Congregation for the Doctrine of Faith (1990, n. 12) warns against monistic or pantheistic syncretism in the use of Eastern methods of meditation. The problem of a pantheistic tendency may also feature in Islamic theology (Ventura 2000). Obviously further research into horizontal mysticism is needed among adherents of Oriental religions in order to arrive at a fully fledged, empirically tested common core theory or diversity theory that covers both types of mysticism: the vertical and the horizontal.

In conclusion, this brief study underscores the significance of a comparative model of mystical experience. The distinction between vertical and horizontal mysticism looks promising for further theory building. Our findings also point to the limitations of Hood's Mysticism Scale (already foreseen by him) when it comes to comparing very different religions like Semitic and Eastern religions (e.g. Hinduism). Hence we think that the major theoretical problem with regard to mysticism still has to be solved: is there a core structure of mystical experience or does it imply diversity? To answer this fundamental question more comparative research among members of different religions in different geographical contexts is needed.

\subsubsection{Personal Characteristics and Vertical Mysticism}

We found only a limited number of personal characteristics that relate to vertical mysticism. As a result the prediction of 'vertical mysticism' with the help of regression analysis was disappointing. Several characteristics do not relate to vertical mysticism: socio-cultural characteristics like age, language and urbanization; and some socio-economic characteristics like caste and educational level of parents. Further research is needed to see whether agreement with mysticism changes across different personal characteristics and whether this change is the same for members of different religions. 